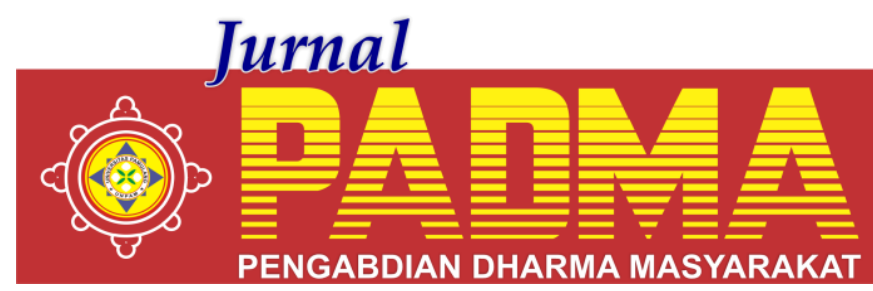

\title{
PERSONAL FINANCIAL PLANNING
}

\author{
${ }^{1 *}$ Hadijah Febriana, ${ }^{2} J e n i$ Irnawati, ${ }^{3}$ Vega Anismadiyah, ${ }^{4}$ Vidya Amalia Rismanty, \\ 5 Wirawan Suryanto \\ Universitas Pamulang, Tangerang Selatan, Banten, Indonesia \\ *dosen02182@unpam.ac.id
}

\begin{abstract}
Abstrak
Pelatihan ini bertujuan agar para santri di Yayasan Pondok Pesantren Yatim Al Hanif yang masih berusia remaja memahami pentingnya perencanaan keuangan untuk membantu para santri tersebut dalam mengatur keuangan saat ini atau di masa yang akan datang agar keuangannya bisa berjalan dengan baik. Dalam kegiatan ini metode yang dilakukan kepada para santri berupa pelatihan langsung dengan tatap muka di aula yang melibatkan para santri kelas 12 dan pendamping di yayasan tersebut, selanjutnya diskusi dan tanya jawab. Hasil kegiatan adalah bertambahnya keilmuan dan keterampilan para santri di Yayasan Pondok Pesantren Yatim Al Hanif, khususnya di bidang keuangan yaitu perencanaan keuangan yang akan menjadi bekal para santri dalam mengelola keuangan baik di masa saat ini atau di masa yang akan datang. Ilmu yang didapatkan pada kegiatan ini diharapkan mampu diterapkan dalam kehidupan sehari-hari baik untuk diri sendiri atau keluarga.
\end{abstract}

Kata Kunci: Perencanaan Keuangan

\section{Abstract}

This training aims to make students at the Yatim Al Hanif Islamic Boarding School Foundation, who are still in their teens, undersrabd the importance of financial planning to help these students manage theiw finances now or in the future so that their finances can run well. In this activity, the method applied to the students was ni the form of direct training with face to face training in the hall involving 12th grade students and assistants at the foundation, then discussion and question and answer. The result of the activity is the increase in knowledge and skills of the students at the Yatim Al Hanif Islamic Boarding School Fundation, especially in the financial sector, namely financial planning that will provide the students with financial management in the present or in the future. The knowledge gained in this activity is expected to be able to be applied in everyday life for both yourself and your family.

Keywords: Personal Financial Planning

\section{PENDAHULUAN}

Awal tahun 2020 negara Indonesia dikhawatirkan dengan pemberitaan tentang virus corona atau covid 19, yang mana sebelumnya virus ini pertama kali berasal dari Wuhan China. Dengan penularan virus corona yang sangat cepat sehingga korban akibat virus ini pun juga terus bertambah setiap harinya. Untuk menghindari penyebaran virus corona, pemerintah mengambil keputusan dan kebijakan untuk menutup semua fasilitas umum dalam jangka waktu yang tidak dapat ditentukan. Dengan ditutupnya semua sarana umum dan berhentinya roda perekonnomian beserta aktifitasnya tentu akan berakhibat pada dunia bisnis atau usaha. Tak sedikit perusahaan yang melakukan pengurangan karyawan.

Mengutip laman CNN Indonesia, Wakil Ketua Umum Kamar Dagang dan Industri Indonesia (Kadin) bidang UMKM, Suryani Motik menyebutkan warga yang menjadi korban pemutusan hubungan kerja (PHK) akibat pandemic corona bisa mencapai 15 juta jiwa. Dampak dari virus corona ini sangat dirasakan oleh seluruh lapisan masyarakat. Hadirnya wabah corona ini membuat ekonomi jatuh bahkan mampu membuat ekonomi berhenti.

Yayasan Pondok Pesantren Yatim Al Hanif juga merasakan dampak dari pandemic ini. Adanya pandemic ini menyebabkan melemahnya ekonomi di pesantren. Perekonomian harus tetap bertahan dan 
tetap stabil bahkkan harus memanfaatkan peluang serta tantangan yang ada. Yayasan ini menampung anak-anak yatim maupun dhuafa. Visi dan Misi dari Yayasan Pondok Pesantren Yatim Al Hanif adalah meringankan penderitaan anak yatim dan dhuafa dengan membantu pendidikan dan keterampilan, menanamkan nilai-nilai iman, takwa dan akhlakul karimah, mengarahkan kemandirian dengan menciptakan terobosan wirausaha dan menjadikan mediator dan fasilitator antara dermawan dengan anak yatim dan dhuafa. Sesuai dengan Visi da Misi Yayasan Pondok Pesantren Yatim Al Hanif para santri diharapkan mampu mengelola keuangan dengan baik untuk dirinya sendiri atau pun untuk usahanya kelak. Semakin cepat para santri mempelajari dasar keuangan maka hasilnya juga akan semakin baik karena nantinya para santri tersebut akan memahami tentang merencanakan keuangan sejak dini.

Apabila para santri tidak mampu merencanakan keuangan membuat para santri tersebut menjadi boros dan berperilaku konsumtif dan membuat mereka menjadi remaja yang tidak bertanggung jawab. Perilaku konsumtif yang dilakukan oleh remaja ataupun orang dewasa pada saat ini merupakan suatu realita yang ada (Imawati dkk, 2013). Menurut Margaretha \& Pambudhi (2015) menyatakan perilaku konsumtif adalah perilaku membeli tidak rasional dan membeli karena sebuah pengakuan. Karakter seperti ini, akan sulit untuk menjadi wirausaha. Pemborosan dan berperilaku konsumtif ini dapat diminimalkan dengan melakukan perencanaan keuangan untuk saat ini atau di masa yang akan datang.

Para santri di Yayasan Pondok Pesantren Yatim Al Hanif, seperti remaja pada umumnya, belum mengetahui tentang apa itu perencanaan keuangan dan pentingnya perencanaan keuangan di masa yang akan datang. Mereka belum memahami pentingnya mempelajari dan mempraktikkan perencanaan keuangan sejak dini. Pentingnya pendidikan dan perencanaan keuangan perlu ditekankan pada seseorang sejak awal (Priya dkk, 2015) Ketidaktahuan ini disebabkan karena kurangnya informasi yang mereka terima dari orang tua atau lingkungan mereka.
Dengan melakukan perencanaan keuangan seseorang akan lebih bijak menyikapi mana yang menjadi kebutuhan dan mana yang tidak menjadi kebutuhan atau hanya keinginan.

Kegiatan pengabdian kepada masyarakat dari tim dosen dan mahasiswa Universitas Pamulang hadir di Yayasan Pondok Pesantren Yatim Al Hanif dalam bentuk pelatihan mengenai personal financial planning.

\section{METODE}

Dalam kegiatan ini metode yang dilakukan kepada para santri di Yayasan Pondok Pesantren Yatim Al Hanif adalah berupa pelatihan langsung dengan tatap muka di aula dengan melibatkan para santri kelas 12 dan pendamping di yayasan tersebut, selanjutnya forum diskusi dengan para santri di aula, dengan adanya forum diskusi ini memberikan fasilitas kepada para santri untuk mengajukan pertanyaanpertanyaan terkait dengan perencanaan keuangan. Untuk kegiatan yang dilakukan di dalam ruangan, digunakan alat bantu microphone sebagai pengeras suara. Selain itu, untuk lebih memberikan gambaran visualisasi yang menarik dan jelas, maka setiap kegiatan yang dilakukan menggunakan proyektor dan laptop. Setiap kegiatan dilaksanakan dalam program ini didokumentasikan dalam bentuk foto dan video.

\section{HASIL DAN PEMBAHASAN}

Kegiatan Pengabdian Kepada Masyarakat ini berhubungan dengan perencanaan keuangan pada para santri. Semakin cepatnya para santri mempelajari dasar keuangan maka hasilnya juga akan semakin baik karena nantinya para santri tersebut akan memahami tentang merencanakan keuangan sejak dini. Apabila para santri tidak mampu merencanakan keuangannya menyebabkan para santri tersebut menjadi boros dan berperilaku konsumtif.

Pembororsan dan perilaku tersebut bisa diminimalkan dengan mengelola keuangan yang baik. Menurut Chomaria (2015) ada beberapa langkah yang bisa dilakukan ketika hendak melakukan pengelolaan keuangan: 
1. Menganalisis kondisi keuangan. Langkah ini merupakan pijakan awal menilai kondisi rill keuangan saat ini apakah berlebih, cukup atau kurang. Hal ini disesuaikan dengan berbagai keinginan yang akan dicapai dimasa masa mendatang. Setiap individu mempunyai keinginan yang tidak sama. Kondisi keuangan saat ini menunjukkan situasi mapan cukup, atau kurang bisa dijadikan pijakan dalam menentukan kebijakan yang berhubungan dengan masalah keuangan.

2. Membuat rencana keuangan. Sejak awal mulailah membuat prencanaan keuangan pribadi

3. Melakukan berbagai implementasi. Setelah membuat perencanaan lakukanlah apa yang telah direncanakan, perencanaan keuangan bersifat sangat luwes sehingga memungkinkan melakukan beberpa penyesuaian demi tercapainya keinginan yang lebih penting.

4. Melakukan monitoring. Hal yang terakhir dilakukan adalah dengan memonitor keuangan apakah sudah berjalan sesuai dengan rencana. Dengan perencanaan penggunaan keuangan lebih terkontrol dan mempermudah pencapaian cita-cita keuangan tersebut.

Perencanaan keuangan bukan hanya dilakukan oleh seseorang yang sudah berkeluarga, namun harus diterapkan sejak dini. Belum banyak remaja yang memiliki kesadaran bahwa pentingnya perencanaan keuangan. Para santri merasa belum memiliki tanggungan, hanya memikirikan untuk dirinya sendiri. Para santri juga tidak mempersiapkan tabungan untuk masa yang akan datang, sehingga jika terjadi wabah seperti wabah corona seperti ini yang menyebabkan perekonomian di Indonesia melemah maka mereka merasakan dampaknya seperti kesulitan dalam memenuhi kebutuhan saat ini atau kebutuhan di masa yang akan datang. Kebutuhan saat ini seperti biaya makan, pembelian pulsa telepon gengam sedangkan kebutuhan yang akan datang seperti kebutuhan naik haji atau kebutuhan di masa tua nanti.

Menabung merupakan salah satu solusi untuk para santri dapat mengelola keuangannya dengan baik sehingga tujuan keuangannya dapat tercapai. Seperti contoh seorang santri berencana untuk naik haji 15 tahun ke depan dengan harga 50 juta. Apabila seorang santri sudah berencana dan mempersiapkan tabungan untuk naik haji maka santri tersebut dapat mencapai tujuan keuangannya.

Dengan melakukan perencanaan keuangan seseorang akan lebih bijak dalam menyikapi mana yang menjadi kebutuhan dan mana yang menjadi keinginan. Menurut Murniati (2013) ada yang membagi keseluruhan proses menjadi tiga tahapan yaitu: identifikasi tujuan , menyusun rencana dan melaksanakan rencana keuangan tersebut. Perencanaan keuangan membuat para santri mampu menggambarkan kondisi keuangan pribadinya sehingga para santri tersebut akan mengalokasikan keuangannya dengan jelas dan memotivasi untuk lebih giat dalam mengumpulkan uang.

Perencanaan keuangan untuk para santri di Yayasan Pondok Pesantren Yatim Al Hanif diharapkan menjadi bekal para santri dalam mengelola keuangannya dengan baik untuk saat ini atau di masa yang akan datang. Dengan melakukan perencanaan keuangan para santri dapat mengelola keuangannya dengan baik, memaksimalkan sumber pendapatan yang mereka miliki, Para santri juga mampu hidup hemat, mulai berfikir untuk investasi atau memiliki pendapatan pasif, mengurangi kecemasan akan keuangannya dimasa yang akan datang dan para santri dapat mencapai tujuan keuangannya.

\section{PENUTUP}

Hasil kegiatan pengabdian kepada masyarakat di Yayasan Pondok Pesantren Yatim Al Hanif berjalan dengan baik sesuai dengan yang diharapkan tim pelaksana pengabdian kepada masyarakat. Para santri terlihat sangat semangat mempelajari materi personal financial planning. Selain itu, hasil kegiatan pengabdian kepada masyarakat ini adalah bertambahnya keilmuan dan keterampilan para santri di Yayasan Pondok Pesantren Yatim Al Hanif, khususnya dibidang keuangan yaitu perencanaan keuangan yang akan menjadi bekal para santri dalam mengelola keuangan, baik di masa saat ini atau di masa yang akan datang. Ilmu yang mereka dapatkan pada kegiatan 
pengabdian kepada masyarakat ini diharapkan mampu memberikan semangat dan motivasi terhadap para santri, serta dapat diterapkan dalam kehidupan seharihari baik untuk dirinya sendiri atau keluarganya.

\section{DAFTAR PUSTAKA}

Chomaria, Nurul. 2015. Cerdas Financial ala Keluarga Muslim. Jakarta: PT. Elex Media Komputindo

Febriana, Hadijah. 2021. Korban PHK akibat Corona. (On line) Dari : https://www.cnnindonesia.com/ekon omi/

Haque, M. G., Nurjaya, N., Affandi, A., Erlangga, H., \& Sunarsi, D. (2021). Micro Financial Sharia Non-bank Strategic Analysis: a Study at BMT Beringharjo, Yogyakarta. Budapest International Research and Critics Institute (BIRCI-Journal): Humanities and Social Sciences, 4(2), 1677-1686.

Imawati, Indah, Susilaningsih \& Elvia Ivada. 2013. Pengaruh Financial Literacy Terhadap Perilaku Konsumtif Remaja Pada Program IPS SMA Negeri 1 Surakarta Tahun Ajaran 2012/2013. Surakarta: Jupe UNS. VOL 2.

Margaretha, Farah \& Sari Siti May. 2015. Faktor Penentu Tingkat Literasi Keuangan Para Pengguna Kartu Kredit di Indonesia; Jakarta. Jurnal akuntansi $\&$ Investasi. Vol

Murniati, Mukhlisin. 2013. Sakinah Finance, Solusi Mudah Mengatur Keuangan
Keluarga Islami, Solo:Tinta Medina, Cet. Ke-1

Nufus, K., et al (2020). Analysis of Financial Performance: Case Study of PT. X Employee Cooperative. Utopía Y Praxis Latinoamericana. Año: 25, $\mathrm{N}^{\circ}$ Extra 10, 2020, pp. 429-444

Priya, A. R. S., Krishnaraj, R., \& Chitra, M. (2015). A study on awareness of personal financial planning among pharma students in Chennai City. International Journal of Pharmaceutical Sciences Review and Research, 33(2), 25-29. Retrieved from

http://globalresearchonline.net/journ alcontnts/v33-2/06.pdf

Putrin I.K. 2016. Perencanaan Keuangan Pada Mahasiswa Ekonomi Islam Di Yogyakarta. JIE Lariba Vol. 2 (1)

Ridwan, M. 2015. The Handbook of Family Financial Planning. Febi UIN-SU Press. Medan.

Subiaktono. 2013. Pengaruh Personality Traits Terhadap Perencanaan Keuangan Keluarga. Jurnal Dinamika Manajemen, 4 (2), 149-160.

Susanti, N., et al (2020). The Effects of Profitability, Leverage, and Liquidity on Financial Distress on Retail Companies Listed on Indonesian Stock Exchange. Jurnal Ilmiah Ilmu Administrasi Publik, 10(1), 45-52. 